DOI: https://doi.org/10.47405/mjssh.v7i1.1217

\begin{tabular}{|c|c|}
\hline 4.581 & Malaysian Journal of Social Sciences and Humanities (MJSSH) \\
\hline $\begin{array}{l}\text { Malaysian Journal of } \\
\text { socal s ciences and }\end{array}$ & Volume 7, Issue 1, January 2022 \\
\hline (MJ-SSH) & e-ISSN : 2504-8562 \\
\hline & $\begin{array}{l}\text { Journal home page: } \\
\text { www.msocialsciences.com }\end{array}$ \\
\hline
\end{tabular}

\title{
The Changing World: A Literature Review on The Significant Roles of Millennial Women in Malaysia
}

\author{
Nurulainy Mohd Noor ${ }^{1}$, Vivien W. C. Yew ${ }^{1}$, Nur Hafizah Yusoff ${ }^{1}$ \\ ${ }^{1}$ Center for Research in Development, Social and Environment, \\ Faculty of Social Sciences and Humanities, Universiti Kebangsaan Malaysia (UKM), \\ 43600 Bangi, Selangor, Malaysia \\ Correspondence: Nurulainy Mohd Noor (nurel889@gmail.com)
}

\begin{abstract}
Every generation is uniquely featured by naturally designed specific characteristics. A generation is influenced by different backgrounds and upbringing, a major factor that differentiates each generation. Specifically, the significance of new millennial women's role varies from one country to another. The study aims to analyse the significant roles of millennial women in Malaysia by reviewing empirical studies and performing a relevant literature search through specific terms related to the topic. Resultantly, millennial women's rising earning power provided significant empowerment and stability. High human capital investment also allowed millennial women to manage the changing family institution that indirectly impacts the stability of society. Finally, the study revealed that new millennial women are transforming and continually evolving to navigate a changing world.
\end{abstract}

Keywords: millennial generation; millennial women, empowerment, changing world, Malaysia

\section{Introduction}

Millennials are known as the Net Generation, Echo Boomers, Nexters, the Nexus Generation, and Generation Y (Twenge, 2010; Burke \& Ng, 2006; Strauss \& Howe, 2000; Zemke et al., 2000; Barnard et al., 1998). Popular studies typically use the term millennials (PEW Research Centre, 2018). Millennials comprise approximately two billion of the world population, whereby half are women (Flood, 2015). Millennials were born between 1981 and 1996 (Dimock, 2019) and are considered the most-studied generation in history. The generation is defined as grown up immersed in the world of digital technologies (Tapscott, 1998) and raised with a digital affluence mindset (Prensky, 2001). Furthermore, the PEW Research Center reported that millennials are the largest generational cohort to date (Fry, 2015). Millennials are the biggest generational group since Baby Boomers. The concurrent advent of this generation represents a major demographic and sociological phenomenon that globally contributes to dominant implications (Chaudhuri \& Ghosh, 2011). Specifically, Malaysia faces a similar impact due to the latest reported statistic pattern on the country population. Hence, understanding millennial behaviour is essential to strategise future social issues and solutions. Lancaster and Stillman (2002) stated that the Gen X population, which is currently half of the millennials and mostly retiring baby boomers, creates possible social issues, such as burnout.

Therefore, the projection of social issues and solutions needs to be investigated based on specific generation behaviours. The massive generation is best learned from a parenting perspective, namely 
the same strategies the parents used to raise them. Myers (2007) listed several approaches, mainly providing substantial support, coddling, and indirectly instilling a sense of belonging. Another focal point about millennials is that giving flexibility forms positive outcomes. Previous studies have investigated millennial women's roles and their contributions to social, economic, and leadership development (Parker, 2012; Devillard, et al. 2013; Flood, 2015; Laurie, 2016). Nonetheless, few studies highlight the significant roles of millennial women in Malaysia. Hence, the study aims to review and analyse the relevant literature on millennial women's roles in contributing to society in this changing world. The following are the two main research questions guiding the study: (i) What are the characteristics of millennials? (ii) What are the roles of millennial women in Malaysia that make them significant?

\section{Literature Review}

\section{Defining Millennials}

The term millennials differentiate between the earlier generations of Silent Generation or Veterans (born from 1928 to 1945), Baby Boomers (born from 1946 to 1964), and Generation X (born from 1965 to 1980). Each generation has different personalities and life values (Ng et al., 2012; Sheahan, 2005). For millennials, ethnic and diversities through technology significantly influence the rapidly changing world (Buckley et al., 2001). The PEW Research Centre (2018) stated four different generations by age, as shown in Table 1 .

Table 1: Four Different Generations by Ages

\begin{tabular}{lll}
\hline Generation's Name & Born & Generation Age in 2018 \\
\hline Gen Z & Between 1997 onwards & 18 and below \\
Millennial & $1981-1996$ & $19-34$ \\
Gen X & $1965-1980$ & $35-50$ \\
Baby Boomer & $1946-1964$ & $51-69$ \\
\hline
\end{tabular}

Source: PEW Research Centre (2018)

As the boomers' children, millennials appreciate different beliefs, values, and attitudes than their parents (Eddy et al., 2010). Millennials grow up with the memory of their boomer parents working long hours only to fall victim to corporate downsizing, frequent layoffs, and high divorce rates (Loughlin \& Barling, 2001). Resultantly, millennials resolve towards 'making a life' over 'making a living' (Zhang et al., 2007). For instance, Bernama (2019) and other media reported that $80 \%$ of Malaysian online users spend a daily average of eight hours and five minutes on the Internet versus the average ideal two hours and 58 minutes for social media consumption. The increase significantly indicates how the millennials adapt to the change in their lifestyles.

\section{Millennial Women in Malaysia}

A new talent era appeared in the form of female millennials. This talented generation is entering a workforce different from what their mother and grandmother may or may not encounter and with a distinct career mindset. The female millennial is better educated, more self-assured and career-focused than previous generations. The $\mathrm{PwC}$ (2015) and Flood (2015) mentioned that female millennials would account for approximately $25 \%$ of the global workforce by 2020 . Forming talent strategies specific to this talent segment is critical to any long-term viability of organisations. The status quo will no longer suffice if employers capitalise on the strengths of the significant portion of the current and future talent pool. In truly addressing the gender leadership gap, organisations must pursue parallel 
efforts to improve leadership diversity while developing talented junior women for future leadership roles. Organisations must be prepared to respond to major issues and the changing world. A one-sizefits-all approach will not work for the entire workforce and millennials. Organisations must also consider female millennials changing needs, depending on their career stage. Hence, committing to an inclusive culture, talent processes, policies, and programmes will support a business model that enables all talent, including female millennials, to thrive. Ultimately, everyone benefits when talent rises to the top (PwC, 2015). Conversely, millennials and Gen $\mathrm{Zs}$ are more pessimistic in the ten years they have been polled after experiencing one of the most difficult years of their lives. The answers to questions about the pandemic, equality, the environment, and the role of business indicate a desire to take up the mantle from those doing too little to improve society and address the crucial issues. Deloitte Global's (2021) survey reported that millennial women are done waiting for change and are taking steps to hold others accountable. Nevertheless, the women recognise that their actions are insufficient to reverse climate change, achieve pay and wealth equality, and end racism and bigotry. The millennial women want governments, educational systems, and businesses to collaborate for large-scale changes. In Malaysia, millennial women were approximately 12 million based on the last census conducted in 2020 by the Department of Statistics Malaysia (DOSM, 2020). Table 2 presents the population pyramid of Malaysians in 2020 by race and gender. Specifically, Bumiputera was the largest ethnic group in the country followed by Chinese and Indian. Furthermore, the number of females is higher than males in every population age range.

Table 2: Malaysian Population Pyramid in 2020

\begin{tabular}{ccccccc}
\hline & \multicolumn{5}{c}{ Races and Gender } \\
\cline { 2 - 6 } Age & \multicolumn{2}{c}{ Bumiputera } & \multicolumn{2}{c}{ Chinese } & \multicolumn{2}{c}{ Indian } \\
\cline { 2 - 7 } & Male & Female & Male & Female & Male & Female \\
\hline & & & & & 3.8 & 5.2 \\
$85+$ & 39 & 50.6 & 26.3 & 36.4 & 5.2 & 7.8 \\
$80-84$ & 52 & 63.8 & 41 & 45.8 & 8.4 & 11.6 \\
$75-79$ & 82 & 94.6 & 62.2 & 66 & 20.3 & 25.6 \\
$70-74$ & 154 & 168.1 & 109.6 & 112.4 & 31.3 & 36.7 \\
$65-69$ & 237 & 249.9 & 145.6 & 142.9 & 46 & 51.7 \\
$60-64$ & 341 & 357.1 & 188.5 & 177.1 & 57.2 & 60 \\
$55-59$ & 434 & 437.4 & 219 & 200.2 & 58.5 & 64.9 \\
$50-54$ & 481 & 501.8 & 225.5 & 224 & 64.2 & 65.9 \\
$45-49$ & 529 & 538.1 & 236.9 & 222.7 & 74.1 & 72.1 \\
$40-44$ & 596 & 585 & 247.8 & 229.6 & 88 & 88 \\
$35-39$ & 771 & 767.8 & 266.4 & 260.8 & 92.9 & 89.9 \\
$30-34$ & 852 & 862.2 & 267.3 & 264.9 & 90.4 & 89 \\
$25-29$ & 943 & 927.8 & 280.9 & 266.4 & 88.6 & 87.4 \\
$20-24$ & 954 & 916 & 266.4 & 254.4 & 85.9 & 82.9 \\
$15-19$ & 974 & 929.8 & 254.2 & 240.3 & 75.8 & 72.8 \\
$10-14$ & 938 & 891.9 & 222.4 & 209.2 & 72.2 \\
$5-9$ & 993 & 937.8 & 209.6 & 199.6 & 74.6 & 71.8 \\
$0-4$ & 1,067 & $1,006.6$ & 207.4 & 197.5 & 74.6 & \\
& & & & & &
\end{tabular}

Source: DOSM (2020)

Parker (2012) contended that millennial women were raised to instil good leadership in life and better at appreciating life values than males. The growing number of millennial women in the workforce signifies the increase in ambitious, well-educated and multi-talented groups of women (Laurie, 2016). Contrarily, Devillard et al. (2013) emphasised that the stagnating number of women moving into leadership indicated a brain drain that creates negative social impacts globally. Millennial women leaving the industry for family matters will reinforce the stereotype and indicate that the industry is incompatible with work-life priorities. Conclusively, millennial women were better educated than males and armed with the knowledge and wittiness in adventuring technology. Facebook is reportedly the chosen media platform widely used in Malaysia, with an outstanding 70\% users, which confirmed that the domination was mainly the millennial women in the country (We Are Social, 2021). 
The Digital 2020 Global Overview Report revealed that 3.8 billion people use social media, thus suggesting that the role of technology in our lives has reached new heights. More people spend more time doing things online. For example, the number of people using the Internet worldwide has reached 4.54 billion, a $7 \%$ increase (298 million new users) since January 2019. In January 2020, 3.80 billion social media users worldwide were recorded, an increase of more than 9\% (321 million new users) since last year. Additionally, over 5.19 billion people worldwide use mobile phones, with user numbers increasing by 124 million (2.4 per cent) in the last year (We Are Social 2021). As of January 2020, Malaysia is among the top 10 internet users from 16 to 64 years old (We Are Social 2021). The average amount of time spent daily on any device in hours and minutes are dominated by the Philippines (9 hours 45 minutes), South Africa (9 hours 22 minutes), Brazil (9 hours 17 minutes), Columbia ( 9 hours 10 minutes), Thailand ( 9 hours 1 minute), Argentina ( 8 hours 47 minutes), Mexico (8 hours 21 minutes), Indonesia (7 hours 59 minutes), Malaysia (7 hours 57 minutes), and Taiwan ( 7 hours 57 minutes).

The strong characters of millennial women, such as being well-educated and empowered, encourage them to stand up for themselves to preach fairness (Stanko, 1997). Furthermore, millennial women bravely follow their chosen path and are determined to find fulfilment in many different ways. Their allegiances are to be earned and will not remain if challenged. Unfavourable circumstances will urge them to re-evaluate their values before taking the next action. Regarding the high percentage of literacy among the generation, the brain drain epidemic may strike in the long term due to many reports of this generation. Millennial females are a group of women with strong will and do not tolerate wrong treatment. Flood (2015) urged serious attention to handling gender equality issues as millennial women are estimated at one billion globally. Therefore, the millennial women's bravery in facing life is now puzzled due to various gender-biased issues and expectations to fulfil traditional gender roles (Stanko, 1997). Ng et al. (2012) believed that millennial women have the same accepted life values that pervade national borders through technology usage on social media. Hence, the study attempted to review empirical analysis on millennial women's roles.

\section{Research Methodology}

Relevant search terms (millennial, women, significant role, empowerment, and Malaysia) were used during a rigorous literature review across disciplines, multiple academic databases, and scholarly search engines, such as ProQuest, IEEE Xplore, Taylor and Francis, Scopus, and Google Scholar. Moreover, the literature was compiled from scholarly journals and seminar proceedings published within the last seven years. The final review included ten articles published between 2014 to 2021 across disciplines, such as human resources, business, marketing, social psychology, sociology, psychology, management, education, family, and women's studies (Ismail \& Lu, 2014; PwC, 2015; Abd Majid et al., 2019; Garcia-Alonso et al., 2019; ManpowerGroup, 2020; Singh \& Tarofder, 2020; Daud \& Wan Hanafi, 2021; Deloitte, 2021; Jayasingam, Lee \& Zain, 2021; Rozlana \& Subramaniama, 2021). Table 3 demonstrates the literature review matrix for the selected references.

Table 3: Literature Review Matrix

\begin{tabular}{lll}
\hline Author (Year) & Source & Key Findings \\
\hline $\begin{array}{l}\text { Ismail and Lu } \\
(2014)\end{array}$ & $\begin{array}{l}\text { Journal of International } \\
\text { Management Studies, } \\
9(1), 38-49 .\end{array}$ & $\begin{array}{l}\text { The authors examined how Hofstede's cultural } \\
\text { values, such as power distance, individualism vs } \\
\text { collectivism, masculinity vs femininity, uncertainty } \\
\text { avoidance, long-term vs short-term orientation, and } \\
\text { indulgence vs restraint, influenced the millennial } \\
\text { career goals. }\end{array}$
\end{tabular}


Abd Majid et al. Religación, 4, 9-16. (2019)

Garcia-Alonso et al. (2019)

ManpowerGroup (2020)

Singh and Tarofder (2020)

Daud \& Wan

Hanafi (2021).

Deloitte Global

(2021)

\section{Boston Consulting Group, 1-6.}

millennials and how to position a company and talent strategies to attract, retain, engage, and develop this important talent pool.

The paper aims to investigate the characteristics of millennials as they are described in most literature. Millennials have seven distinct characteristics; each was the subject of the current study. Because most literature on millennial characteristics is in a Western context, this paper investigates the similarities in millennial characteristics descriptions among public university students.

Companies and individuals, both men and women, can perform various activities to ease the mental burden. Although completely removing the mental burden will be difficult, the steps outlined by the authors will facilitate in alleviating the burden and pave the way for more women and men to have successful, fulfilling careers while having a successful, fulfilling life at home.

Most generations, especially Gen Z, are motivated by money. Although payment is essential to Gen Y, flexibility is more important to them. Generally, flexibility and challenging work are crucial to Gen $\mathrm{Y}$ women and men.

The study findings revealed a link between worklife balance, work environment, job satisfaction, and the desire to leave. Contrarily, job engagement, diversification, flexibility, and technology did not affect the intention to leave among female millennial employees.

Millennials prefer leaders who are innovative, inspirational, and visionary. Organisations and managers who recognise and understand generational differences and leadership style preferences have an advantage in effectively leading their diverse workforce. Resultantly, the organisations can increase productivity and gain a competitive advantage, benefiting the company and employees.

Millennials and Gen Zs came of age when online platforms and social media gave them the ability and power to share their opinions, influence distant people and institutions, and question authority in new ways. The forces have shaped their worldviews, values, and behaviours.

Jayasingam, Lee \& Current Psychology, 1Zain (2021)

12.
To balance between the family and work domains, the terms work-life balance and work-family balance are used interchangeably. The terms are 
noticeable in collectivist countries, such as Malaysia. Nonetheless, putting a premium on family without considering the needs of employees with various demographic profiles could lead to a work-life conflict.

Rozlana \& Subramaniama (2021)
International Seminar on Human Resource Development (ICHRD) 2021.
The study discovered that gender, marital status, and caring responsibilities impact millennials' mental health in Malaysia. Flexible working arrangements (FWA) positively impact millennials mental health, well-being, and productivity in Malaysia. The implementation of FWAs in Malaysia is a matter of "when" rather than "if." Hence, the study is useful in developing a more structured FWA policy, particularly in the postcoronavirus disease (COVID-19) era when flexibility is a necessity rather than a luxury.

\section{Research Findings and Discussion}

\section{The Characteristics of Millennials}

Millennial women have special characteristics. For example, millennial women prefer innovative, inspirational, and visionary leaders (Daud \& Wan Hanafi, 2021). The COVID-19 pandemic curtailed millennial and Gen Z activities, but not their desire to be heard. The Deloitte Global Millennial Survey (2021) mentioned that the pandemic, extreme climate events, and a tense socio-political climate have fuelled people's passions and given them oxygen. Abd Majid et al.'s (2019) study revealed several interesting findings of the selected millennials, such as confirmation of characteristics. Specifically, Malaysian undergraduate millennials did not disclose certain commonly accepted characteristics of millennials.

The results showed that sociocultural and socioeconomic factors have an impact on how people, including millennials, think and act in society. The characteristics include feeling special and sheltered, confident and achievement-oriented, team-oriented, pressured, and conventional (Abd Majid et al., 2019). The Corporate Leadership Council (2005) acknowledged that events, such as the September 11 terrorist attacks had influenced millennials to re-evaluate their life priorities. Meanwhile, Strauss and Howe (2000) disclosed that millennials are well educated, ethnically diverse, affluent, sheltered, conventional, and team-oriented. Millennials also appreciate the same values as the Boomers cohort, including desiring work-life balance, flexible work schedules, opportunities to give back to the community and society, and non-monetary rewards (Hewlett et al., 2009). The significant social part that differentiates the generations is Baby Boomers living in a stable family environment with both parents, whereas the millennials usually grow up with divorce, single parenting, and absent parents (Strauss \& Howe, 2000). Millennial children learn to adapt by substituting and satisfying emotional needs with technology through digital media as part of everyday life.

Consequently, millennial behaviours are often interpreted as direct, to the point of appearing rude, as the generation believes in living life 'above average'. The strong, confident level is due to millennials upbringing by the Boomer parents, who constantly ensure success in any situation. Interestingly, Twenge (2010) concluded that although millennials are raised with constant praise and self-esteem throughout their childhood and made them an optimist, the harsher realities of adulthood would overwhelm those not mentally prepared to face economic trials, financial issues or even competition. The situation contributes towards highly individual action and ignorance towards social approval (Kelan, 2012). Twenge and Campbell (2008) also highlighted how millennials face an external locus of control as this signifies the mentality of having little impact or control over how events unfold in 
their lives. The generation would easily fall into the blaming game or even attribute the outcome to luck to refuse responsibility for the situation (Kelan, 2012). Furthermore, millennials prefer handling life on their own due to their strong dependence on technology, a strong factor contributing to a higher level of anxiety and depression amongst the millennials (Twenge \& Campbell, 2008).

The tendency to be impacted by opinions shared on social media may be well received by some but can trigger individuals towards depression. Nevertheless, millennials value diversity and multiculturalism as they develop a greater awareness of the world through technologies that embrace appreciation, tolerance, and sensitivity to work with diverse ethnic backgrounds (Pryor et al., 2009). Myers and Sadaghiani (2010) emphasised that millennials have no issues in leading the upcoming virtual globalisation. Alsop (2008) and Twenge (2006) labelled millennials as the trophy kids as they demonstrate a sense of entitlement attributed to their pampered upbringing by Boomer parents as they thrive on instant gratification and believe in multitasking as a way of life. Summarily, millennials are born with choices provided by technologies. Therefore, expectations on a greater array of options are considered their birth rights. In order to take advantage of better options, millennials expect flexibility and constant feedback on progress. In Malaysia, technology is the primary source for millennials as they always prefer speed to accomplish something in their lives. Through technology, millennials excel at multitasking as it enables fast learning and completion of any given task simultaneously. Millennials are technologically savvy and know how to manipulate technology to achieve what they want.

Digital data in Malaysia showed 26.69 million internet users compared to the total population of 32.16 million in 2020. Approximately 26.00 million Malaysians are active mobile social users, with an average of 7 hours 57 minutes of daily time spent with media. Generally, Malaysians spend 2 hours 45 minutes on social media, 2 hours 59 minutes watching television, 1 hour 26 minutes listening to music and streaming services, and 1 hour 4 minutes using a game console (We Are Social, 2021). Safer (2008) explained that millennials are hardworking, clever, and resourceful, while Howe and Strauss (2003) acknowledged that millennials might demand more time for extra activities. Nevertheless, their skills and team-oriented spirit ultimately enable millennials to get the job done. Moreover, millennials love the colourful graphics, creative audio, full-motion multimedia, and constant interactivity as they spend long hours embracing the world of technology. The generation also loves exploring the outside world by travelling and would have different ethnicity close friends.

Communication is vital to millennials as it translates into freedom of mobility. Sweeney (2006) concluded that millennials are a generation with no tolerance for delay. The generation expects fast responses from others (Oblinger \& Oblinger, 2005) and seeks convenience in searching for information (Van Scoyoc \& Cason, 2006). Besides being an instrument for socialising, the Internet encourages the millennial generation to openness, immediacy, investigation, and forming doubts about authenticity (Smith, 2010). Similarly, Tapscott (1998) described the millennials as freely expressive and needing to authenticate. Technology made the generation very independent (Rushkoff, 1996) as their online communication styles of living everyday life revolved around instant messaging (IM) and chat rooms (Walter \& Mediavilla, 2005). Furthermore, millennials prefer active involvement in learning and evolve through discovery (Oblinger \& Oblinger, 2005), causing a long time spent browsing the Internet and greater critical thinking skills and judgment (Tapscott, 1998). The need to have the latest technology is now necessary for millennials to remain intact (Marketing Breakthroughs Inc., 2008). The generation accesses digital media daily and in constant close relation globally. The generation is brilliant in managing technology, driving smooth communication everywhere and making the world borderless. Traditionally, the millennials were considered innovators and early adopters of technology, including online reviews and other social media venues (Mangold \& Smith, 2011). The millennials who lead in adopting technology and online information sources will magnify as Generation X, and Baby Boomers follow suit.

Additionally, millennials value the Internet as a sense of control. The characteristic determines the situation with the people they interact with and on what website, using the Internet as a medium to express their opinions, thoughts, and emotions. Alsch (2000) highlighted that millennials need more time for themselves and want less structured lives. The desire parallels with their sentiments of 'there 
is more to life'. Thus, relationships and lifestyle are the two priorities for many millennials. Habrich, Bobek and Horvat (2021) reported that women's participation in the workforce is increasing but still significantly lower than men's participation. The main issues are cultural stereotypes, limited job market access, and difficulties combining work and childcare. Moreover, remote areas are still underdeveloped in terms of infrastructure and educational opportunities. Gender bias is still prevalent in rural society.

In the future, eliminating these stereotypes and improving (and enforcing) women-related policies could increase female workforce participation. Millennials view work and balance as enough time spent at work and adequate time allocated for family, friends, and personal interests. The level of success, rich or poor, is irrelevant as everyone has the same 24 hours per day to pursue goals (Smith, 2010). Millennials define life as beyond material and constantly searching for meaningful and soulfulfilling aspects (Yang \& Guy, 2006; Lancaster \& Stillman, 2002). Values and impressive missions interest millennials. For instance, Price Waterhouse Coopers (2008) observed that millennials appreciate activities involving uplifting society. The situation emphasised the vital need for work-life balance as part of a substantial evolution in social media. Arham et al. (2019) found that household responsibilities and financial needs exacerbate work-life conflicts.

Work-life conflicts worsen through the rising costs of raising a family and dealing with and balancing work and home responsibilities. Nevertheless, the study found no link between the workplace environment and work-life conflicts. Interestingly, Dharmastuti et al. (2020) revealed that COVID-19 hoaxes had the greatest impact on mothers' mental health due to health-institutional distrust and apparatus-government distrust. Due to the lack of cooperation in promoting the protocol, the COVID19 pandemic prevention efforts were hampered. Specifically, physiology, psychology, spirituality, cognitive ability, and social interaction are the five components that constitute the happiness indicator for women. True happiness can be achieved when all elements are connected back to the spiritual principle and aligned (Mohd Rosli et al., 2020).

\section{Roles of Millennial Women in Malaysia}

Millennial women have essential roles in their family and career orientation. Hence, millennial women need flexibility and balance in their daily work-life activities. Singh and Tarofder's (2020) study stressed the significance of identifying the contributing variables that lead to a female millennial employee's intention to leave their job for human resource practises in organisations. Work-life balance, job satisfaction, and the likelihood of turnover should be considered in talent retention strategies. Meanwhile, Garcia-Alonso et al. (2021) discussed how to reduce the mental stress that holds women back, arguing that women have more workloads than their male counterparts. Employers should support workplace flexibility in today's workforce. Observably, women as leaders and employers have recognised the value of work flexibility in attracting and retaining talent. Although millennial women value flexibility more than millennial men, men should experience how to be more available dads or caregivers and share the burden of household work. Thus, flexibility is crucial for her and desirable for him (Manpower, 2020). Jaysingam, Lee and Zain (2021) argued that the non-work domain should include family obligations and personal activities instead of limited to family obligations. The emphasis on striking a work-family balance should not compromise the well-being of employees with fewer or no family responsibilities. Rozlana and Subramaniama (2021) found that FWA positively influenced millennial mental health, well-being, and productivity. Meanwhile, Ismail and $\mathrm{Lu}$ (2014) highlighted the necessity of maintaining practical interventions for human resource development professionals to manage the dynamic younger workforce from a career development perspective.

This maintenance is done by incorporating the six cultural values in explaining millennial career goals. Due to the prominent roles millennial women play, greater effort should be placed in understanding the uniqueness of this particular group as a key factor in measuring progress towards gender equality. The literature on millennials' roles includes various disciplines, such as human resource management, business, marketing, social psychology, sociology, psychology, management, education, family 
studies, and women's studies (Rokis et al., 2018; Arham et al., 2019; Dharmastuti et al., 2020; Mohd Rosli et al., 2020; Habrich et al., 2021; Hanim \& Naiemah, 2021; Lydia \& Vighnarajah, 2021; Rozlana \& Subramaniama, 2021; Suleman, 2021; Theopilus et al., 2021). For example, cultural influences shape the beliefs and values of a generation, which is significant to social acceptance and development. Chun et al. (2003) studied how culture positively influences millennial women's interpretation of success, achievements, expectations, advancement, and attainment. In Malaysia, millennial women are vital from the perspective of the Women Declaration of the country (Dasar Wanita Negara, 1989) due to their diversity in skills and leadership. Millennial women's contributions could build a dynamic and competitive nation. As a multiracial country, Malaysia possesses rich cultures and values. Potentially, a successful millennial woman in Malaysia is defined as early as when they marry. Wang and Taylor (2011) stated that millennials at the same age are slower to marry than their counterparts in older generations. Millennials were marked at $22 \%$, while Generation X recorded that three in ten were married and four in ten for Baby Boomers. Conversely, millennial women look forward to marrying and having children as they link marriage with parenthood.

The generation brought clear change from the reversal of gender roles whereby young women surpass young men in prioritising their life (Lavelle, 2016). Maimunah and Hoo (2014) described the generation as those living and working in the era of wider opportunities to education and training, multiple organisational and occupational settings, and wider geographical mobility through technology sophistication. The environment change presented the generation with peculiar cultural values on significant life events that constructed them to be more self-directed, boundaryless, intelligent with protean dominant features (Taylor, 2012; Briscoe \& Hall, 2006). Many millennial women are now exposed to the importance and value of work-life balance through technology, becoming their focal point when making life decisions. Flexibility is the highly sought-after word for many millennial women regarding commitment as it compliments their motherhood instinct in raising a family. For example, holiday hours, flexible time and telecommuting are essential points that need affirmation. Smith (2010) highlighted work-life balance as vitally important towards living a positive life, satisfaction in making a decision and leading an ethical way of life.

For many millennial women in Malaysia and globally, the critical factor is a deep-rooted attitude that a woman should be the primary caregiver. Villalobos (2014) reported that millennial women were doing more unpaid work than men, facing specific challenges in matters of childbearing. Bianchi et al. (2012) and Sayer et al. (2009) mentioned an unequal division of household responsibilities between men and women in dual-earner households with children. The unequal involvement in household chores between men and women, particularly in childbearing, is often associated with increased workfamily conflict within the family. Undeniably, traditional gender roles still affect the way men and women manage their daily interactions. A massive nation that faces social conflict will cause a major economic meltdown. Therefore, a deep understanding of millennial women and strategising how to reduce and eliminate the conflict is critical. Wang and Taylor (2011) concluded that millennials stand on marriage institutions is now obsolete, whereby single parenting is accepted as the norm. Specifically, MaNIS (2018) revealed that the number of members of the single mother cooperative in Malaysia increased by $6 \%$ from 2016. Twenge (2010) concluded that the phenomenon is due to upbringing and the mothers of millennial girls working outside the home. Past studies also showed that millennial women traditionally embrace masculine traits, such as ambition and independence, creating a big group of women with amazing self-esteem.

Twenge (2010) confirmed millennial women's belief in their young children surviving even if the mother works. Additionally, the Department of Statistics Malaysia reported that the divorce rate has improved by 3\% from 2016 to 2017 (DOSM, 2018). The data indicate a good sign that millennial women are starting to present their self-reliance. Considering the density of the generation population, anything positive or even negative impacting the community will have a dominant ripple effect through society's demographical or even sociological perspective. Therefore, an issue may become an epidemic without close observation and a proper contingency plan. Habrich et al. (2021) stressed the impact of growth, culture, education, and female-related regulations on women's decision to work or ability to work. Work-life conflicts are exacerbated by the rising costs of raising a family and coping with and balancing work and home duties (Arham et al., 2019). Hence, millennials mental health in 
Malaysia is influenced by gender, marital status, and caregiving obligations. Furthermore, FWA may improve millennials mental health, well-being, and productivity (Rozlana \& Subramaniama, 2021). Millennial women in Malaysia is moving towards individualism and self-reliance. A divorce is an expensive event involving hiring different legal advisors and dividing assets to start over again, surviving with a single income. What happens to the millennial generation will impact the economy and stability of the country on a larger scale due to being the majority population. Many recent studies have proven a significant link between divorce rate and economic health (Haury, 2019; De Vaus et al., 2015; Mielach, 2012). A high divorce rate will affect productivity, which burdens the economy. Divorce invites the need for more housing, energy, transportation, and other important resources.

Meanwhile, a strong society comprising mainly highly educated millennials within the country is a crucial contributor to human capital that determines how to contribute to the economy, which is valued through their knowledge and skills. Therefore, a healthy economy requires a country to work on the elements needed to boost human capital. The statistics on the divorce rate can be reduced through a stable and constant change in the family dynamic. Moreover, a healthy dynamic family equals member being helpful with each other within the family system. Correspondingly, Sustainable Development Goal No. 3 ensures a healthy life and promotes well-being for all ages (United Nations, 2016). Wellbeing is a complex combination of physical, mental, emotional, and social health factors. Ultimately, maintaining a family dynamic for the millennials in Malaysia is fundamental to social development. The country will continue to prosper with financial benefits from a healthy marriage society over a long period.

\section{Conclusion}

The study analysed most recent studies on millennial women characteristics and their significant roles in family, workplace and society. As more millennial women assume power and take control at the workplace, further studies should be conducted to explore the motivating factors underlying this new generation. The study implication suggested that the traditional sex-role differentiation invited interdependence and produced organic solidarity that contributed crucially to the stability of the modern family of the millennial generation.

\section{Acknowledgement}

The publication of this paper was supported by the MPOB-UKM Endowment Chair and Research Grant EP-2019-054 


\section{References}

Abd Majid, F., Mokhtar, S., Muzlia, S., Shahril, W. N. E. H., Subramaniam, K., \& Mohamad, M. (2019). The Malaysian Millennials' Characteristics: An Investigation on Selected Public Universities. Religación, 4, 9-16.

Alsch, M. (2000). The echo-boom generation: A growing force in American society. Futurist, 34(4), $42-46$.

Alsop, R. (2008). The trophy kids grow up: How the millennial generation is shaking up the workplace. New York, NY: Jossey-Bass.

Arham, A. F., Norizan, N. S., Ridzuan, A. R., Alwi, S. N. N. N. S., \& Arham, A. F. (2019). Work-Life Conflicts among Women in Malaysia: A Preliminary Study. International Journal of Academic Research in Business and Social Sciences, 9(9), 614-623.

Barnard, R., Cosgrove, D., \& Welsh, J. (1998). Chips \& pop: Decoding the nexus generation. Toronto: Malcolm Lester Books.

Bernama. (2019). Malaysia's population is now estimated to be 32.6 million. New Straits Time. Retrieved from https://bit.ly/2GsVfv2.

Bianchi, S. M., Sayer, L. C., Milkie, M. A. \& Robinson, J. P. (2012). Housework: Who did, does or will do it, and how much does it matter? Social Forces, 91(1), 55-63.

Buckley, M. R., Beau, D. S., Novicevic, M. M. \& Sigerstad, T. D. (2001). Managing generation X: Individual and organisational perspectives. Review of Business Jamaica, 22(1/2), 81-85.

Burke, R. J. \& Ng, E. (2006). The changing nature of work and organisations: Implications for human resource management. Human Resource Management Review, 16, 86-94.

Briscoe, J. P. \& Hall, D. (2006). The interplay of boundaryless and protean careers: Combinations and implications. Journal of Vocational Behaviour, 69(1), 4-18.

Chaudhuri, S., \& Ghosh, R. (2011). Reverse Mentoring. Human Resource Development Review, 11(1), 55-76.

Chun, K. M., Balls Organista, P. \& Marín, G. (2003). Acculturation: Advances in theory, measurement, and applied research. Washington, DC: American Psychological Association.

Corporate Leadership Council. (2005). HR considerations for engaging generation $Y$ employees. Washington, DC: Corporate Executive Board.

Dasar Wanita Negara (Women Declaration). (1989). Kementerian Pembangunan Wanita dan Keluarga Malaysia. Retrieved from https://bit.ly/2p7Oshi.

Daud, S., \& Wan Hanafi, W. N. (2020). The Generic Attributes of the New Millennial Leaders. The Journal of Asian Finance, Economics, and Business, 7(12), 455-464.

De Vaus, D., Gray, M., Qu, L. \& Stanton D. (2015). The economic consequences of divorce in six OECD countries. Australian Institute of Family Studies. Retrieved from https://bit.ly/2JQS16G.

Deloitte Global. (2021). A call for accountability and action: The Deloitte Global 2021 Millennial and Gen $Z$ survey. Retrieved from https://bit.ly/3EVniPL

Department of Statistics Malaysia. (2020). Malaysia's Population Pyramid 2010 - 2040. Retrieved from https://bit.ly/3GNjUHr

Devillard, S., Sancier, S., Werner, C., Maller, I. \& Kossof, C. (2013). Women matter 2013. Gender diversity in top management: Moving corporate culture, moving boundaries. France: McKinsey and Company.

Dharmastuti, A., Apriliyanti, F., \& Wahyuni, F. (2020). Exploring the Impact of COVID-19 Hoax on the Mental Health of Millennial Moms. KnE Social Sciences, 408-429.

Dimock M. (2019). Defining generations: Where Millennials end and Generation Z begins. Retrieved from https://pewrsr.ch/2D7o5PI.

Eddy, S. W., Schweitzer, L. \& Lyons, S. T. (2010). New generation, great expectations: A field study of the millennial generation. Journal of Business and Psychology, 25, 281-292.

Flood, A. (2015). The female millennial: A new era of talent. Retrieved from Price Waterhouse Cooper website: https://pwc.to/2SHf8TZ.

Fry, R. (2015). Millennials overtake baby boomers as America's largest generation. Pew Research Center, FactTank. Retrieved from https://pewrsr.ch/2JQk4Tw.

Garcia-Alonso, J., Krentz, M., Lovich, D., Quickenden, S., \& Taplett, F. B. (2019). Lightening the mental load that holds women back. Boston Consulting Group, 1-6.

Global Digital. (2018). Global digital report 2018. Retrieved from: https://bit.ly/2Fx8urq. 
Habrich, V., Bobek, V., \& Horvat, T. (2021). The Influence of Economic Activity of Women in Malaysia and Guatemala on National Development. In Emerging Markets. Intech Open.

Hanim, H., \& Naiemah, S. U. (2021). Determinants of women leadership in the Malaysian manufacturing industry. In AIP Conference Proceedings (Vol. 2339, No. 1, p. 020146). AIP Publishing LLC.

Haury, A. C. (2019). How divorce can adversely affect the economy. Investopedia. Retrieved from https://bit.ly/2Zc0WVB

Hewlett, S. A., Sherbin, L., \& Sumberg, K. (2009). How gen Y and boomers will reshape your agenda. Harvard Business Review, 87, 71-76. Retrieved from https://hbr.org.

Howe, N. \& Strauss, W. (2003). Millennials go to college. Washington, DC: American Association of Collegiate Registrars and Admissions Officers.

Ismail, M., \& Lu, H. S. (2014). Cultural values and career goals of the millennial generation: An integrated conceptual framework. Journal of International Management Studies, 9(1), 38-49.

Jayasingam, S., Lee, S. T., \& Zain, K. N. M. (2021). Demystifying the life domain in work-life balance: A Malaysian perspective. Current Psychology, 1-12.

Juliano, J. J. (2004). Gen-X and Gen-Y: Teaching them the business. Public Utilities Fortnightly, 142(6), 82-85.

Kelan, E. K. (2012). Rising stars, developing millennial women as leaders. United Kingdom: Palgrave Macmillan.

Lancaster, L. C. \& Stillman, D. (2002). When generations collide. New York: Harper Collins.

Laurie, A. L. (2016). Millennial women in leadership: A new generation of women still facing gender inequalities in business leadership. Pepperdine University: ProQuest Dissertations Publishing.

Lavelle, L. A. (2016). Millennial women in leadership: A new generation of women still facing gender inequalities in business leadership. Pepperdine University: Graduate School of Education and Psychology.

Loughlin, C. \& Barling, J. (2001). Young workers' work values, attitudes, and behaviours. Journal of Occupational and Organizational Psychology, 74, 543-558.

Lydia, D., \& Vighnarajah, S. (2021). Role of English Language as a Literacy Tool in Shaping the Perception of Women's Empowerment. International Journal of Education and Literacy Studies, 9(3), 52-63.

Maimunah, I. \& Hoo, S. L. (2014). Cultural values and career goals of the millennial generation: An integrated conceptual framework. Journal of International Management Studies, 9(1), 2.

Mangold, W. G. \& Smith, K. T. (2011). Selling to millennials with online reviews. Business Horizons, 55(2), 141-153.

ManpowerGroup Malaysia. (2020). It's flexibility, if you want to attract and retain Gen $Y$ in the workforce. Retrieved from https://bit.ly/3IPA2tS

Marketing Breakthroughs Inc. (2008). Five tips on successfully advertising to Gen-Y. Retrieved from https://bit.ly/3oW6eE0

Mielach, D. (2012). Why divorce is bad for the economy. Mother Nature network. Retrieved from https://bit.ly/2Mh4eTQ.

Mohd Rosli, N. A., Suhaimi, H., Saari, Z., Siwok, S. R., Abdul Latif, A., Masroom, M. N., Syed Yusof, S. K., \& Othman, N. (2020). Happiness in Islamic Perspectives among Multi-Tasking Women in Malaysia. UMRAN - International Journal of Islamic and Civilisational Studies, 6(32), 125-137. https://doi.org/10.11113/umran2020.6n3-2.427

Myers, J. (2007). The how and Y profit. October 2007.

Myers, K. \& Sadaghiani, K. (2010). Millennials in the Workplace: A communication perspective on millennial's organisational relationships and performance. Journal of Business Psychology, 25, 225-23.

Ng, E. S., Lyons, S. T. \& Schweitzer, L. (2012). Managing the new workforce: International perspectives in the millennial generation. Cheltenham: Edward Elgar.

Oblinger, D. G. \& Oblinger, J. L. (2005). Educating the net generation (Educause). Retrieved from https://bit.ly/2YuwYPa.

Parker, K. (2012). The boomerang generation: Feeling ok about living with mom and dad. Washington, DC: Pew Social and Demographic Trends. Retrieved from https://pewrsr.ch/2GuCmb4. 
DOI: https://doi.org/10.47405/mjssh.v7i1.1217

Prensky, M. (2001). Digital natives, digital immigrants. Retrieved from http://www.marcprensky.com/writing.

Price Waterhouse Coopers. (2008). Millennials at work: Perspectives from a new generation. Retrieved from https://pwc.to/2GuJPqJ.

Pryor, J. H., Hurtado, S., DeAngelo, L., Sharkness, J., Romero, L. C., Korn, W. S. \& Trans, S. (2009). The American freshman: National norms for 2008 (Research Brief). Los Angeles: Higher Education Research Institute at the University of California. Retrieved from https://bit.ly/2LHnJVQ.

PwC. (2015). The female millennial: A new era of talent. Retrieved from https://pwc.to/3dQ2ZY7

Rokis, R., Basir, N., \& Fauzi, F. N. M. (2018). Poverty, women's empowerment and social entrepreneurship among B40 urban women in Malaysia. In Proceeding: 2nd International Conference on Social Sciences, Humanities And Technology (ICSHT 2018) (pp. 559-564).

Rozlana, N. Z. A., \& Subramaniama, G. (2021). Flexible working arrangements and millennials: Does "Work Better" Lead to "Feel Better"? International Seminar on Human Resource Development (ICHRD) 2021.

Rushkoff, D. (1996). Playing the future: How kids' culture can teach us to thrive in an age of chaos. New York: HarperCollins.

Safer, M. (2008). The millennials are coming. Retrieved from https://cbsn.ws/2SEyQzx.

Sayer, L. C., England, P., Bittman, M. \& Bianchi, S. M. (2009). How long is the second (plus first) shift? Gender differences in paid, unpaid and total work time in Australia and the United States. Journal of Comparative Family Studies, 40(4), 523-545.

Sheahan, P. (2005). Generation Y: Thriving and surviving with Generation Y at work. Prahran: Hardie Grants Book.

Singh, M. K. H., \& Tarofder, A. K. (2020). Identifying the Predictors of Intention to Leave Among the Female Employees in Malaysia. Psychology and Education Journal, 57(9), 686-699.

Suleman, D. (2021). Women Discrimination in Malaysia: Examining 'The Gender Agenda' from the Viewpoint of Lenore Manderson's Women, Politics, and Change. Linguistica Antverpiensia 2021(1):2204-2222.

Ministry of Women, Family and Community Development Malaysia (KPWKM). (2018). Sistem Maklumat Nasional Isu-isu Sosial (MaNIS). Retrieved from https://bit.ly/2GtXnmc.

Smith K. T. (2010). Work-life balance perspectives of marketing professionals in generation $Y$. Services Marketing Quarterly, 31(4), 434-447.

Stanko, E. A. (1997). Should I stay or should I go? Some thoughts on the variants of intimate violence. Violence Against Women, 3(6), 629-635.

Strauss, W. \& Howe, N. (2000). Millennials rising: The next great generation. New York, NY: Vintage Books.

Sweeney, R. (2006). Millennial behaviors and demographics. Retrieved from https://bit.ly/2LH2QKA.

Tapscott, D. (1998). Growing up digital: The rise of the Net Generation. New York: McGraw-Hill.

Taylor, J. (2012). Public service motivation and work preferences of the millennials in Australia. In E. S. Ng, S. T. Lyons, \& L. Schweitzer (Eds.), Managing the New Workforce: International Perspectives in the Millennial Generation (pp. 20-41). Cheltenham: Edward Elgar.

Theopilus, Y., Yogasara, T., Theresia, C., \& Ardine, D. (2021). Customer experience analysis of cosmetics retail store on millennial women. Engineering Management in Production and Services, 13(2), 29-45.

Twenge, J. M. (2006). Generation me: Why today's young Americans are more confident, assertive, entitled and more miserable than ever before. New York, NY: Free Press.

Twenge, J. \& Campbell, S. (2008). Generational differences in psychological traits and their impact on the workplace. Journal of Managerial Psychology, 23(8), 862-877.

Twenge, J. M. (2010). A review of the empirical evidence on generational differences in work attitudes. Journal of Business Psychology, 25, 201-210.

Twenge, J. M. \& Campbell, S. M. (2012). Who are the millennials? Empirical evidence for generational differences in work values, attitudes and personality. Cheltenham: Edward Elgar.

United Nations. (2013). National, regional and global estimates and projections of the number of women aged 15 to 49 who are married or in a union, 1970-2030. Population Division. 2013/2.

United Nations. (2016). Goal 3: Good health and well-being. Retrieved from https://bit.ly/2GVufWN. 
Van Scoyoc A. M., \& Cason, C. (2006). The electronic academic library: Undergraduate research behaviour in a library without books. Portal: Libraries and the Academy, 6(1), 47-58.

Villalobos. A. (2014). Motherload: Making it all better in insecure times. Oakland: University of California Press.

Walter, V. A. \& C. Mediavilla. (2005). Teens are from Neptune, librarians are from Pluto: An analysis of online reference transactions. Library Trends, 54(2), 209-227.

Wang W. \& Taylor P. (2011). Millennials, parenthood trumps marriage. Pew Social and Demographic Trends. Retrieved from https://pewrsr.ch/2Y7ChVC.

We Are Social. (2021). Digital 2020: Global Digital Overview. Retrieved from https://bit.ly/3oSMAZb

Yang, S. \& Guy, M. E. (2006). GenXers versus boomers: Work motivators and management implications. Public Performance and Management Review, 29, 267-284.

Zemke, R., Raines, C. \& Filipczak, B. (2000). Generations at work: Managing the clash of veterans, boomers, Xers and Nexters in your workplace. New York, NY: American Management Association.

Zhang, Y., Straub, C. \& Kusyk, S. (2007). Making a life or making a living? Cross-cultural comparisons of business students' work and life values in Canada and France. Cross-Cultural Management: An International Journal, 14, 174-195. 